\title{
KARAKTERISTIK TEMPAT TUMBUH POHON PALAHLAR GUNUNG (Dipterocarpus retusus Bl.) DI KAWASAN HUTAN LINDUNG GUNUNG CAKRABUANA, SUMEDANG, JAWA BARAT (The Site Characteristics of Palahlar Gunung (Dipterocarpus retusus Bl.) in Protected Forest of Cakrabuana Mountain, Sumedang, West Java)*)
}

\author{
Oleh/By: \\ Istomo $^{1)}$ dan/and Andita Pradiastoro ${ }^{2)}$ \\ 1) Bagian Ekologi, Departemen Silvikultur, Fakultas Kehutanan IPB Jl. Lingkar Akademik Kampus IPB Darmaga \\ Po. Box 168 Bogor 16680 Telp. +62-251-626806, Fax +62-251-626886 Email : ecology@ipb.ac \\ 2) Alumnus Fakultas Kehutanan IPB \\ *)Diterima : 29 September 2009; Disetujui : 13 Agustus 2010
}

\begin{abstract}
Palahlar gunung (Dipterocarpus retusus Bl.) is one tree species of Dipterocarpaceae family which has high value and occurs in West Java. However, this species was threatened with extinction, and the technique for its culture has not been known yet. The objectives were to study the characteristics of growth site of palahlar gunung. This research was conducted in the protection forest area of Gunung (Mountain) of Cakrabuana, Sumedang, West Java. This research was conducted by establishing observation strips as wide as $20 \mathrm{~m}$ with direction perpendicular to contour line, from altitude of 1,000-1,600 $\mathrm{m}$ above sea level, as many as three strips with distance between strips was $500 \mathrm{~m}$. Research results showed that palahlar gunung trees were found at altitude ranging from 1,000 $\mathrm{m}$ to $1,225 \mathrm{~m}$ asl with slope of 4-100\% in Latosol soil, with texture ranging from silty loam to clay, with soil acidity level ranging from acid to slightly acid. At altitude of 1,000$1,099 \mathrm{~m}$ asl there were found palahlar gunung trees as many as 9 trees. At altitude of 1,100-1,199 $\mathrm{m}$ asl there were found as many as 12 trees, and at altitude of 1,200-1,299 $\mathrm{m}$ asl there were found as many as 5 trees. In slope class of 26-50\%, abundance of palahlar gunung was the greatest, namely 15 trees. In slope class 51-75\%, abundance of palahlar gunung was as many as 5 and 4 trees, and the smallest abundance of palahlar gunung occurred at slope class $76-100 \%$, namely as many as 2 trees.
\end{abstract}

Keywords: Abundance, altitude, slope, soil texture

\begin{abstract}
ABSTRAK
Palahlar gunung (Dipterocarpus retusus Bl.) adalah salah satu jenis pohon famili Dipterocarpaceae yang bernilai tinggi yang terdapat di Jawa Barat. Keberadaan jenis tersebut terancam punah dan belum diketahui pembudidayaannya, oleh karena itu dengan tujuan untuk mengkaji karakteristik tempat tumbuh palahlar gunung (Dipterocarpus retusus Bl.) penelitian ini dilakukan. Penelitian dilakukan di wilayah Hutan Lindung Gunung Cakrabuana, Sumedang, Jawa Barat. Penelitian dilakukan dengan jalur pengamatan lebar $20 \mathrm{~m}$, arah tegak lurus kontur dari ketinggian 1.000-1.600 m dpl sebanyak tiga jalur dengan jarak antar jalur $500 \mathrm{~m}$. Hasil penelitian menunjukkan bahwa pohon palahlar gunung (Dipterocarpus retusus Bl.) dijumpai pada ketinggian 1.000 sampai $1.225 \mathrm{~m}$ dpl dengan kelerengan 4-100\% pada tanah Latosol yang bertekstur geluh debuan sampai lempung dengan tingkat kemasaman tanah masam sampai cukup masam. Pada ketinggian 1.000-1.099 m dpl pohon palahlar gunung (Dipterocarpus retusus Bl.) sebanyak sembilan pohon. Pada ketinggian 1.100-1.199 m dpl ditemukan sebanyak 12 pohon dan pada ketinggian 1.200-1.299 m dpl ditemukan sebanyak lima pohon. Pada kelas lereng 26-50\% kelimpahan palahlar gunung (Dipterocarpus retusus $\mathrm{Bl}$.) paling besar yaitu sebanyak 15 pohon. Pada kelas lereng 51-75\% kelimpahan palahlar gunung (Dipterocarpus retusus Bl.) sebanyak lima dan empat pohon dan kelimpahan palahlar gunung (Dipterocarpus retusus Bl.) paling kecil terdapat pada kelas lereng 76-100\% yaitu sebanyak dua pohon.
\end{abstract}

Kata kunci: Kelimpahan, ketinggian tempat, lereng, tekstur tanah 


\section{PENDAHULUAN}

Pohon-pohon dari suku Dipterocarpaceae adalah penghasil kayu utama di hutan hujan tropika Asia Tenggara, terutama terdapat di wilayah Indonesia. Kebanyakan pohon-pohon Dipterocarpaceae merupakan pohon besar yang mendominasi tajuk utama hutan, sehingga sering disebut pohon dominan. Diketahui pula bahwa Indonesia memiliki kekayaan jenis pohon Dipterocarpaceae tertinggi di dunia, dari 512 jenis pohon anggota suku Dipterocarpaceae, 386 jenis di antaranya terdapat di wilayah Asia Tenggara, terutama di Indonesia (Newman et al., 1999). Jenis pohon terbanyak adalah anggota marga Shorea atau meranti dan marga Dipterocarpus atau keruing umumnya berupa pohon besar dengan batang lurus dan berbanir.

Marga Dipterocarpus terdiri atas 70 jenis, terbanyak terdapat di Kalimantan 41 jenis dan empat jenis di antaranya ditemukan di Jawa (Newman et al., 1999). Marga Dipterocarpus yang ditemukan di Pulau Jawa, yaitu palahlar (Dipterocarpus hasseltii Blume), keladan atau palahlar beurit (Dipterocarpus gracilis Blume), palahlar gunung (Dipterocarpus retusus Blume) dan lalar atau kelahlar (Dipterocarpus littoralis Blume). Jenis D. hasseltii, D. gracilis, D. retusus dilaporkan terdapat di hutan alam di Jawa Barat dan Jawa Tengah bagian selatan dan $D$. littoralis hanya ditemukan di $\mathrm{Pu}-$ lau Nusakambangan, Cilacap, Jawa Tengah. Akibat tekanan penduduk yang lapar lahan di Pulau Jawa, telah terjadi peningkatan yang luar biasa kegiatan penebangan liar dan perambahan hutan di $\mathrm{Pu}-$ lau Jawa yang memperparah kerusakan hutan dan mempercepat punahnya jenis pohon lokal yang bernilai tinggi di Pulau Jawa, termasuk palahlar. Sampai saat ini tidak banyak informasi tentang keberadaan palahlar di Jawa Barat termasuk penyebaran, karakteristik tempat tumbuh, dan teknik budidaya dalam rangka penyelamatan dan pengembangan palahlar ( $D$. retusus).
Dipterocarpus retusus $\mathrm{Bl}$., dengan sinonim D. trinervis Bl., D. macrocarpus Vesque, D. pubescens Koord. \& Valeton, mempunyai nama daerah: keruing gunung (Jawa, Sumatera), palahlar gunung (Jawa), jati olat (Sumbawa). Penyebaran pertumbuhan meliputi India, Burma, Laos, Kamboja, Semenanjung Malaysia, Sumatera, Jawa, Bali, Lombok, dan Sumbawa. Pohon berukuran sedang sampai besar tinggi sampai $48 \mathrm{~m}$, batang lurus silindris, tinggi bebas cabang 15-20 m, dan diameter batang setinggi dada sampai 150 cm (Soerianegara and Lemmens, 1994).

Penggunaan kayu ini untuk bahan konstruksi, seperti tiang, gardu telepon, pagar, gerbang kereta api, konstruksi kapal, darmaga serta dasar tiang pancang. Menurut Heyne (1987) kayu ini dapat digunakan untuk bangunan rumah tetapi dianggap kurang awet.

Berdasarkan informasi bahwa salah satu jenis palahlar di Jawa Barat yaitu palahlar gunung (D. retusus), yang selanjutnya disebut palahlar, dilaporkan terdapat di kawasan Hutan Lindung Gunung Cakrabuana. Untuk mendapatkan informasi tentang penyebaran, potensi, dan karakteristik tempat tumbuh palahlar gunung, maka penelitian ini perlu untuk dilakukan. Penelitian dilaksanakan di Hutan Lindung Gunung Cakrabuana, Kabupaten Sumedang, Jawa Barat, yang berada di wilayah kerja KPH Sumedang, BKPH Cadasngampar, RPH Cakrabuana, Perum Perhutani Unit III Jawa Barat dan Banten.

Tujuan penelitian ini adalah:

1. Mengkaji penyebaran pertumbuhan jenis palahlar di Hutan Lindung Gunung Cakrabuana.

2. Mengkaji pengaruh ketinggian tempat, topografi, dan sifat-sifat tanah terhadap keberadaan jenis palahlar di Hutan Lindung Gunung Cakrabuana.

Manfaat penelitian ini adalah untuk mendapatkan informasi kondisi tempat tumbuh alami jenis palahlar gunung dalam rangka penyelamatan dan pengembangan jenis palahlar gunung di luar habitat aslinya melalui penanaman. 


\section{BAHAN DAN METODE}

\section{A. Waktu dan Lokasi Penelitian}

Penelitian dilaksanakan pada bulan Oktober 2003 berlokasi di Hutan Lindung Gunung Cakrabuana, Kabupaten Sumedang, Jawa Barat yang berada di KPH Sumedang, BKPH Cadasngampar, RPH Cakrabuana, Perum Perhutani Unit III Jawa Barat dan Banten.

\section{B. Bahan dan Alat Penelitian}

Bahan dan alat yang diperlukan dalam penelitian ini adalah kawasan hutan alam Hutan Lindung Gunung Cakrabuana, peta rupa bumi, peta kerja, altimeter, clinometer, kompas, haga hypsometer, phi band, tambang plastik, tali rafia, parang, kantong plastik, sasak bambu, tally sheet, alat tulis, alkohol, etiket gantung, kamera, dan seperangkat komputer untuk pengolahan data.

\section{Metode Penelitian}

\section{Pengambilan Data Lapangan}

\section{a. Data Vegetasi}

Data vegetasi yang dikumpulkan dari lapangan adalah nama jenis dan jumlah individu tumbuhan tingkat semai dan pancang untuk jenis palahlar dan non palahlar. Nama jenis, diameter setinggi dada, dan tinggi tumbuhan tingkat tiang dan pohon untuk jenis palahlar dan non palahlar. Kriteria tumbuhan tingkat pohon adalah tumbuhan berkayu dengan diameter setinggi dada mencapai diameter 20 $\mathrm{cm}$ atau lebih. Tumbuhan tingkat tiang adalah tumbuh berkayu muda dengan diameter setinggi dada antara 10 sampai 20 $\mathrm{cm}$. Tumbuhan tingkat pancang adalah anakan pohon dengan tinggi total lebih dari 1,5 m sampai diameter setinggi dada kurang dari $10 \mathrm{~cm}$. Tumbuhan tingkat semai adalah anakan pohon dari mulai kecambah sampai tinggi totalnya kurang dari $1,5 \mathrm{~m}$.

Untuk keperluan identifikasi jenis tumbuhan yang belum dikenal, diambil potongan ranting dan daun yang selanjut- nya diproses sebagai spesimen herbarium. Identifikasi dan determinasi nama jenis tumbuhan yang belum diketahui dilakukan di Herbarium Bogoriense, Puslitbang Biologi LIPI.

\section{b. Pengamatan Sifat Fisik Lingkungan}

Data sifat fisik lingkungan yang diukur di lapangan adalah suhu, kelembaban, topografi, dan sifat-sifat tanah. Topografi meliputi ketinggian tempat dan kelerengan. Pengukuran topografi meliputi ketinggian tempat dari permukaan laut dan kelerengan tempat. Data sifat fisik lingkungan ini diukur pada setiap petak berukuran $20 \mathrm{~m}$ x $100 \mathrm{~m}$. Contoh tanah diambil secara acak pada setiap sub petak $20 \mathrm{~m}$ x $20 \mathrm{~m}$ pada kedalaman $0-20 \mathrm{~cm}$ dan $>20 \mathrm{~cm}$. Contoh tanah yang berasal dari sub petak berukuran $20 \mathrm{~cm}$ x $20 \mathrm{~cm}$ tersebut selanjutnya dicampur (dikomposit) menjadi satu untuk mendapatkan contoh tanah dari petak berukuran $20 \mathrm{~cm} \mathrm{x}$ $100 \mathrm{~cm}$.

\section{Penetapan Pengambilan Contoh}

Metode yang digunakan dalam pengambilan data lapangan adalah gabungan dari metode jalur dengan metode petak ganda (metode line plot systematic sampling). Jumlah jalur yang dibuat sebanyak tiga jalur. Masing-masing jalur diletakkan dari ketinggian $1.000 \mathrm{~m}$ dpl sampai dengan ketinggian $1.600 \mathrm{~m} \mathrm{dpl}$, dengan jarak tiap-tiap jalur adalah $500 \mathrm{~m}$. Pembuatan jalur dilakukan dengan cara memotong kontur/tegak lurus terhadap ketinggian. Penetapan jalur dilakukan secara systematic sampling with random start. Di dalam jalur tersebut dibagi-bagi lagi menjadi petak-petak berukuran $20 \mathrm{~m}$ x 100 m dengan interval tiap-tiap petak adalah $100 \mathrm{~m}$. Terdapat enam petak berukuran 20 m x 100 m di setiap jalur, sehingga untuk ketiga jalur terdapat 18 petak pengamatan atau luas areal penelitian adalah 3,6 ha. Selanjutnya pada setiap petak berukuran $20 \mathrm{~m} \mathrm{x} 100 \mathrm{~m}$ tersebut dibagi lagi ke dalam sub petak-sub petak yang berukuran $20 \mathrm{~m}$ x $20 \mathrm{~m}$. Masingmasing sub petak tersebut kemudian di- 
bagi ke dalam plot-plot pengamatan yang berbentuk bujur sangkar dengan ukuran masing-masing adalah $2 \mathrm{~m} \times 2 \mathrm{~m}$ untuk semai, $5 \mathrm{~m}$ x $5 \mathrm{~m}$ untuk pancang, $10 \mathrm{~m} \mathrm{x}$ $10 \mathrm{~m}$ untuk tiang, dan $20 \mathrm{~m} \times 20 \mathrm{~m}$ untuk pohon.

\section{Analisis Data}

\section{a. Analisis Vegetasi}

Data yang diperoleh di lapangan, selanjutnya dilakukan penghitungan terhadap kerapatan dan kerapatan relatif, frekuensi dan frekuensi relatif, dominansi dan dominansi relatif serta Indeks Nilai Penting (Soerianegara dan Indrawan, 1980). Penghitungannya adalah sebagai berikut:

$$
\begin{aligned}
& \mathrm{K}=\frac{\text { jumlah individu suatu jenis }}{\text { luas total petak contoh }} \\
& \mathrm{KR}=\frac{\text { kerapatan suatu jenis }}{\text { kerapatan semua jenis }} \times 100 \% \\
& \mathrm{~F}=\frac{\text { jumlah petak ditemukan suatu jenis }}{\text { jumlah seluruh petak contoh }} \\
& \mathrm{FR}=\frac{\text { frekuensi suatu jenis }}{\text { frekuensi seluruh jenis }} \times 100 \% \\
& \mathrm{D}=\frac{\text { jumlah luas bidang dasar suatu jenis }}{\text { luas petak contoh }} \\
& \mathrm{DR}=\frac{\text { dominansi suatu jenis }}{\text { dominansi semua jenis }} \mathrm{X} 100 \%
\end{aligned}
$$

\section{b. Indeks Keanekaragaman Jenis}

Untuk menentukan Indeks Dominansi Jenis digunakan rumus sebagai berikut (Simpson, 1949 dalam Misra, 1980):

$$
\mathrm{C}=\sum\left[\frac{n_{i}}{N}\right]^{2}
$$

Dimana :

$\mathrm{C}=$ Indeks dominansi

$\mathrm{N}=$ Total nilai penting

$\mathrm{n}_{\mathrm{i}}=$ Nilai penting masing-masing jenis

Nilai indeks dominansi jenis akan bernilai satu atau mendekati satu apabila 4 dominansi dipusatkan pada satu atau sedikit jenis. Sebaliknya, komunitas hutan yang diamati didominasi oleh banyak jenis, maka nilai indeks dominansi jenisnya akan bernilai rendah atau bahkan mendekati nol.

Keanekaragaman jenis dikuantitatifkan dengan menghitung Indeks Keragaman Jenis (Indeks Shanon-Wiener) sebagai berikut (Margalef, 1968 dalam Misra, 1980):

$\mathrm{H}=-\sum\left[\frac{\mathrm{n}_{\mathrm{i}}}{\mathrm{N}}\right] \log \left[\frac{\mathrm{n}_{\mathrm{i}}}{\mathrm{N}}\right]$

Dimana :

$\mathrm{H}=$ Indeks keragaman Shanon-Wiener

$\mathrm{n}_{\mathrm{i}}=$ Nilai penting tiap jenis (spesies)

$\mathrm{N}=$ Total nilai penting.

Umumnya para ahli ekologi membuat peringkat nilai keragaman tinggi jika nilai $\mathrm{H}^{\prime}>3,0$ sedang nilai $\mathrm{H}^{\prime}$ adalah 2-3 dan rendah jika nilai $\mathrm{H}^{\prime}<2$.

Nilai Evenness dapat dihitung dengan rumus sebagai berikut (Southwood and Henderson, 2000):

$\mathrm{E}_{\mathrm{H}}=\frac{\mathrm{H}}{\log (\mathrm{S})}$

Dimana

$\mathrm{E}_{\mathrm{H}}=$ Indeks kemerataan (evenness)

$\mathrm{H}=$ Indeks Shanon-Wiener

$\mathrm{S}=$ Jumlah jenis (spesies)

Konsep kemerataan ini menunjukkan derajat kemerataan atau kelimpahan individu pada setiap jenis. Jika jumlah individu tumbuhan yang ditemukan tersebar merata pada setiap jenis, maka nilai $\mathrm{E}$ akan mendekati satu, tetapi jika individu yang ada tersebar tidak merata pada setiap jenis, maka nilai $\mathrm{E}$ akan mendekati nol.

Untuk mengukur nilai kekayaan jenis digunakan rumus Margalef dalam Odum (1959) dalam Misra (1980):

$\mathrm{R}=\frac{\mathrm{S}-1}{\log (\mathrm{N})}$,
Dimana :
$\mathrm{R}=$ Indeks Margalef
$\mathrm{S}=$ Jumlah jenis (spesies)
$\mathrm{N}=$ Jumlah total individu

Kekayaan jenis menunjukkan banyaknya jenis dan banyaknya individu pada 
setiap jenis, semakin tinggi jumlah jenis dan jumlah individu setiap jenis, maka nilai $\mathrm{R}$ akan semakin tinggi.

\section{c. Hubungan Kehadiran Palahlar de- ngan Sifat-Sifat Lingkungan}

Untuk mengetahui hubungan antara faktor-faktor lingkungan fisik (ketinggian tempat, topografi, dan sifat-sifat tanah) terhadap keberadaan palahlar dapat dilakukan dengan menggunakan model regresi linier berganda melalui prosedur stepwise (Supranto, 1987). Adapun persamaan umum yang digunakan adalah:

$\mathrm{Y}=\mathrm{a}+\mathrm{b}_{1} \mathrm{X}_{1}+\mathrm{b}_{2} \mathrm{X}_{2}+\mathrm{b}_{3} \mathrm{X}_{3} \ldots+\mathrm{b}_{\mathrm{k}} \mathrm{X}_{\mathrm{k}}$

Dimana :

$\mathrm{Y}=$ Variabel tidak bebas (jumlah pohon palahlar)

$\mathrm{a} \quad=$ Intersep; $\mathrm{b}_{\mathrm{k}}=$ Koefisien regresi

$\mathrm{X}_{\mathrm{k}}=$ Variabel bebas (ketinggian, kelerengan, tekstur tanah, dan $\mathrm{pH}$ )

\section{III.HASIL DAN PEMBAHASAN}

\section{A. Komposisi Jenis}

Berdasarkan hasil analisis vegetasi untuk seluruh jalur dan petak pengamatan dengan luas contoh 3,6 ha ditemukan sekitar 81 jenis tumbuhan yang seluruhnya tergolong ke dalam 34 famili. Untuk tumbuhan tingkat semai ditemukan sebanyak 47 jenis, tingkat pancang sebanyak 61 jenis, tingkat tiang sebanyak 53 jenis, dan tingkat pohon sebanyak 50 jenis. Gambaran mengenai komposisi jenis tumbuhan di kawasan Hutan Lindung Gunung Cakrabuana dapat dilihat dari jumlah jenis dan jumlah individu jenis yang dijumpai pada masing-masing jalur pengamatan di lokasi penelitian. Jumlah jenis untuk masing-masing tingkat pertumbuhan vegetasi pada masing-masing jalur pengamatan dapat dilihat pada Tabel 1. Pada Tabel 1 dapat dilihat bahwa rata-rata jumlah jenis pohon dan permudaannya pada ketiga jalur pengamatan untuk semua tingkat pertumbuhan antara 26 sampai 36 jenis. Jumlah jenis paling tinggi pada tingkat pancang, diikuti tingkat tiang dan pohon, sedangkan jumlah jenis terendah pada tingkat semai.
Berdasarkan perhitungan INP untuk semua jalur telah diketahui urutan jenis tumbuhan yang mempunyai nilai INP tertinggi sampai terendah pada setiap tingkat pertumbuhan. Tiga jenis tumbuhan yang mempunyai urutan INP tertinggi dan urutan INP untuk jenis palahlar dapat dilihat pada Tabel 2. Pada Tabel 2 dapat dilihat bahwa untuk tingkat semai jenis dominan berdasarkan nilai INP adalah pasang (Quercus sundaica) dengan indeks nilai penting sebesar 43,74\%. Pada tingkat pancang dan tiang jenis dominan adalah peutag (Acemena acuminatissima) dengan indeks nilai penting masing-masing sebesar $42,98 \%$ dan 57,54\%. Pada tingkat pohon jenis puspa (Schima walichii) merupakan jenis terbanyak dengan indeks nilai penting sebesar 63,43\%. Sementara untuk jenis palahlar pada tingkat semai berada pada urutan 24 dari 47 jenis. Pada tingkat pancang berada pada urutan 8 dari 61 jenis. Pada tingkat tiang berada pada urutan 9 dari 53 jenis. Pada tingkat pohon berada pada urutan 4 dari 50 jenis, dengan demikian tampak bahwa jenis palahlar bukan merupakan jenis dominan di lokasi penelitian, namun semakin tinggi tingkat pertumbuhan jenis palahlar semakin meningkat tingkat dominasinya terhadap jenis lain.

\section{B. Keanekaragaman Jenis}

Hasil perhitungan indeks keanekaragaman jenis tumbuhan di lokasi penelitian yang meliputi jumlah jenis, nilai indeks dominansi (C), nilai kemerataan jenis (E), nilai indeks keragaman jenis (H'), dan nilai indeks kekayaan (R) untuk ketiga jalur pengamatan dapat dilihat pada Tabel 3.

Pada Tabel 3 dapat dilihat bahwa besarnya nilai indeks dominansi jenis pada berbagai tingkat pertumbuhan tidak berbeda jauh, yaitu sebesar 0,08-0,29 (C < 1), dengan demikian dapat dikatakan bahwa komunitas hutan yang diteliti didominasi oleh banyak jenis terutama pada tingkat pancang dan tiang. 
Tabel (Table) 1. Jumlah jenis tumbuhan pada setiap tingkat pertumbuhan yang ditemukan pada setiap jalur pengamatan (Number of species each growth level at each transect line observation)

\begin{tabular}{ccccc}
\hline \multirow{2}{*}{ No. } & Tingkat pertumbuhan & \multicolumn{3}{c}{ Jumlah jenis per jalur (Number of species each transect) } \\
\cline { 3 - 5 } & (Growth stage) & Jalur 1 (Transect 1) & Jalur 2 (Transect 2) & Jalur 3 (Transect 3) \\
\hline 1 & Semai (Seedling) & 31 & 28 & 25 \\
2 & Pancang (Sapling) & 40 & 41 & 27 \\
3 & Tiang (Poles) & 37 & 29 & 26 \\
4 & Pohon (Tree) & 34 & 34 & 27 \\
\hline \multicolumn{2}{l}{ Rata-rata (Average) } & 36 & 33 & 26 \\
\hline
\end{tabular}

Tabel (Table) 2. Tiga nama jenis yang mempunyai indeks nilai penting tertinggi pada berbagai tingkat pertumbuhan di Hutan Lindung Gunung Cakrabuana (The highest three name species of importance value index at each growth stage in the Cakrabuana Protected Forest area)

\begin{tabular}{lclc}
\hline $\begin{array}{c}\text { Tingkat pertumbuhan } \\
\text { (Growth stage) }\end{array}$ & $\begin{array}{c}\text { No. urut } \\
\text { INP (IVI order) }\end{array}$ & \multicolumn{1}{c}{ Nama jenis (Name of species) } & INP (IVI) (\%) \\
\hline Semai (Seedling) & 1 & Pasang (Quercus sundaica) & 43,74 \\
& 2 & Peutag (Acemena acuminatissima) & 36,70 \\
& 3 & Puspa (Schima walichii) & 26,18 \\
& $\mathbf{2 4}$ & Palahlar (Dipterocarpus retusus) & $\mathbf{1 , 6 7}$ \\
\hline Pancang (Sapling) & 1 & Peutag (Acemena acuminatissima) & 42,98 \\
& 2 & Pasang (Quercus sundaica) & 31,77 \\
& 3 & Puspa (Schima walichii) & 19,27 \\
& $\mathbf{8}$ & Palahlar (Dipterocarpus retusus) & $\mathbf{4 , 7 8}$ \\
\hline Tiang (Poles) & 1 & Peutag (Acemena acuminatissima) & 57,54 \\
& 2 & Pasang (Quercus sundaica) & 39,17 \\
& 3 & Huru (Actinodaphne procera) & 32,30 \\
& $\mathbf{9}$ & Palahlar (Dipterocarpus retusus) & $\mathbf{7 , 4 7}$ \\
\hline Pohon (Tree) & 1 & Puspa (Schima walichii) & 63,43 \\
& 2 & Pasang (Quercus sundaica) & 61,64 \\
& 3 & Peutag (Acemena acuminatissima) & 20,67 \\
\end{tabular}

Keterangan (Remarks): INP (IVI): Indeks Nilai Penting (Importance Value Index)

Tabel (Table) 3. Jumlah jenis dan nilai indeks keanekaragaman jenis pada berbagai tingkat pertumbuhan vegetasi (Number of species and index of diversity for each growth stage)

\begin{tabular}{lcccccc}
\hline $\begin{array}{c}\text { Tingkat } \\
\text { (Growth stage) }\end{array}$ & $\begin{array}{c}\text { Jumlah } \\
\text { jenis } \\
\text { (Number of } \\
\text { species) }\end{array}$ & $\begin{array}{c}\text { Jumlah } \\
\text { individu } \\
\text { (Number } \\
\text { of individual) }\end{array}$ & $\begin{array}{c}\text { Nilai C } \\
(\text { C value })\end{array}$ & $\begin{array}{c}\text { Nilai R } \\
(\text { R value })\end{array}$ & $\begin{array}{c}\text { Nilai E } \\
(\text { E value })\end{array}$ & $\begin{array}{c}\text { Nilai H’ } \\
\left(H^{\prime} \text { value }\right)\end{array}$ \\
\hline Semai (Seedling) & 47 & 516 & 0,13 & 7,36 & 0,69 & 2,26 \\
Pancang (Sapling) & 61 & 693 & 0,12 & 9,17 & 0,69 & 2,82 \\
Tiang (Poles) & 53 & 320 & 0,08 & 9,01 & 0,79 & 3,14 \\
Pohon (Tree) & 50 & 548 & 0,29 & 7,77 & 0,71 & 2,76 \\
\hline
\end{tabular}

Pada Tabel 3 dapat dilihat bahwa nilai $\mathrm{R}$ dalam komunitas hutan di lokasi penelitian 7,36-9,17. Nilai R tertinggi pada tingkat pancang, diikuti tingkat tiang, pohon dan terendah tingkat semai. Hasil tersebut terlihat bahwa tingkat pertumbuhan yang mempunyai jumlah jenis tertinggi akan mempunyai nilai kekayaan jenis tertinggi pula.

Pada Tabel 3 dapat dilihat bahwa kemerataan jenis pada semua tingkat pertumbuhan mendekati 1 , yaitu $>0,69$. Ni6 lai kemerataan tingkat tiang lebih tinggi dibandingkan tingkat pertumbuhan yang lain. Kemerataan jenis untuk semai, pancang, dan pohon hampir sama. Perlu dijelaskan bahwa nilai $\mathrm{E}$ akan berbanding terbalik dengan nilai $\mathrm{C}$, jika nilai $\mathrm{E}$ tinggi, maka nilai $\mathrm{C}$ akan rendah demikian pula sebaliknya, karena dengan meratanya sebaran individu pada setiap jenis, maka menunjukkan tidak adanya jenis yang paling mendominasi. 
Indeks keragaman (H') merupakan derajat keragaman jenis yang menggabungkan nilai $\mathrm{R}$ dan nilai $\mathrm{E}$, sehingga nilai $\mathrm{H}^{\prime}$ selain mencerminkan jumlah jenis, juga mencerminkan kekayaan dan kemerataan jenis. Pada Tabel 3 dapat dilihat bahwa nilai H' di lokasi penelitian berkisar antara 2,26-3,14. Nilai H' tertinggi pada tingkat tiang $(3,14)$ dan terendah tingkat semai $(2,26)$. Tingkat keanekaragaman jenis di lokasi penelitian tergolong sedang sampai tinggi. Nilai keanekaragaman tertinggi pada tingkat tiang, meskipun jumlah jenis dan jumlah individu bukan yang tertinggi, tetapi karena nilai kemerataan pada tingkat tiang tertinggi.

\section{Struktur Hutan}

Banyaknya pohon dan permudaan seluruh jenis dan jenis palahlar pada semua jalur pengamatan disajikan pada Tabel 4 dan Tabel 5. Pada Tabel 4 dapat dilihat banyaknya pohon yang ditemukan untuk semua jenis dan jenis palahlar pada petak contoh seluas 3,6 ha untuk pohon, 0,9 ha untuk tiang, 0,225 ha untuk pancang, dan 0,036 ha untuk semai. Untuk semai seluruh jenis ditemukan 516 individu semai pada luas petak contoh 0,036 ha atau 14.333,3 rata-rata per ha. Demikian pula untuk palahlar, untuk tingkat semai ditemukan 3 individu semai palahlar pada petak contoh seluas 0,036 ha atau 83,3 individu semai palahlar per ha. Pada
Tabel 5 terlihat bahwa persentase rata-rata per ha banyaknya palahlar dibandingkan dengan banyaknya individu seluruh jenis meningkat dengan meningkatnya tingkat pertumbuhan. Pada tingkat semai, persentase palahlar dibandingkan semua jenis hanya $0,58 \%$, pada tingkat pancang menjadi $0,65 \%$, pada tingkat tiang meningkat menjadi 2,50\%, sedangkan pada tingkat pohon meningkat menjadi 4,74\%. Hal ini sejalan dengan tingkat dominasi palahlar dibandingkan dengan jenis lain seperti tertera pada Tabel 2 .

Sebaran banyaknya pohon seluruh jenis dan jenis palahlar pada petak contoh seluas 3,6 ha berdasarkan kelas diameter disajikan pada Gambar 1.

Pada Gambar 1 tampak bahwa bentuk sebaran banyaknya pohon berdasarkan kelas diameter membentuk huruf $\mathrm{J}$ terbalik atau membentuk struktur tegakan normal hutan tidak seumur, yaitu banyaknya pohon paling banyak pada kelas umur rendah dan semakin menurun dengan bertambahnya kelas diameter. Hal yang sama terjadi pada jenis palahlar, jumlah pohon palahlar paling banyak terdapat pada kelas diameter $20-39 \mathrm{~cm}$ sebanyak 15 pohon dan terus menurun hanya 2 pohon pada kelas diameter $120 \mathrm{~cm}$. Pada Gambar 1 dapat dilihat pula bahwa pohon-pohon di lokasi penelitian, baik palahlar maupun non palahlar masih ditemukan pohon-pohon besar dengan diameter batang $>120 \mathrm{~cm}$.

Tabel (Table) 4. Banyaknya pohon dan permudaan yang ditemukan pada setiap jalur pengamatan untuk seluruh jenis dan jenis palahlar (Tree and regeneration abundance for all species and palahlar species)

\begin{tabular}{|c|c|c|c|c|c|c|c|}
\hline \multirow[b]{3}{*}{ No. } & \multirow[b]{3}{*}{$\begin{array}{c}\text { Tingkat } \\
\text { (Growth stage) }\end{array}$} & \multicolumn{6}{|c|}{ Kerapatan individu (Density individual) } \\
\hline & & \multicolumn{2}{|c|}{ Jalur 1 (Transect 1) } & \multicolumn{2}{|c|}{ Jalur 2 (Transect 2) } & \multicolumn{2}{|c|}{ Jalur 3 (Transect 3) } \\
\hline & & $\begin{array}{c}\text { Seluruh jenis } \\
\text { (All species) }\end{array}$ & $\begin{array}{c}\text { Jenis } \\
\text { palahlar } \\
\text { (Palahlar } \\
\text { Species) } \\
\end{array}$ & $\begin{array}{l}\text { Seluruh jenis } \\
\text { (All species) }\end{array}$ & $\begin{array}{c}\text { Jenis } \\
\text { palahlar } \\
\text { (Palahlar } \\
\text { Species) } \\
\end{array}$ & $\begin{array}{l}\text { Seluruh jenis } \\
\text { (All species) }\end{array}$ & $\begin{array}{c}\text { Jenis } \\
\text { palahlar } \\
\text { (Palahlar } \\
\text { Species) } \\
\end{array}$ \\
\hline 1 & Semai (Seedling) & 183 & 1 & 169 & 1 & 164 & 1 \\
\hline 2 & Pancang (Sapling) & 249 & 3 & 230 & 7 & 214 & 8 \\
\hline 3 & Tiang (Poles) & 120 & 1 & 110 & 6 & 90 & 1 \\
\hline 4 & Pohon (Tree) & 211 & 6 & 182 & 17 & 155 & 3 \\
\hline & ta-rata (Average) & 190,75 & 2,75 & 172,75 & 7,75 & 155,75 & 3,25 \\
\hline
\end{tabular}


Tabel (Table) 5. Banyaknya pohon dan permudaan per ha pada semua jalur pengamatan untuk seluruh jenis dan jenis palahlar (Tree and regeneration abundance for all species and palahlar species per hektare size plots)

\begin{tabular}{|c|c|c|c|c|c|c|c|}
\hline \multirow[b]{2}{*}{ No. } & \multirow[b]{2}{*}{$\begin{array}{c}\text { Tingkat } \\
\text { (Growth } \\
\text { stage) }\end{array}$} & \multicolumn{2}{|c|}{$\begin{array}{c}\text { Jumlah individu } \\
\text { (Number of individual) }\end{array}$} & \multirow[b]{2}{*}{$\begin{array}{l}\text { Luas contoh } \\
\text { (Sampling } \\
\text { size) (ha) }\end{array}$} & \multicolumn{3}{|c|}{$\begin{array}{c}\text { Jumlah individu (Number of individual)/ } \\
\text { ha }\end{array}$} \\
\hline & & $\begin{array}{l}\text { Seluruh } \\
\text { jenis (All } \\
\text { species) }\end{array}$ & $\begin{array}{c}\text { Jenis } \\
\text { palahlar } \\
\text { (Palahlar } \\
\text { species) }\end{array}$ & & $\begin{array}{c}\text { Seluruh } \\
\text { jenis (All } \\
\text { species) }\end{array}$ & $\begin{array}{c}\text { Jenis } \\
\text { palahlar } \\
\text { (Palahlar } \\
\text { species) }\end{array}$ & $\begin{array}{c}\text { \% Jenis } \\
\text { palahlar } \\
\text { (Palahlar } \\
\text { species) }\end{array}$ \\
\hline 1 & $\begin{array}{l}\text { Semai } \\
\text { (Seedling) }\end{array}$ & 516 & 3 & 0,036 & $14.333,3$ & 83,3 & 0,58 \\
\hline 2 & $\begin{array}{l}\text { Pancang } \\
\text { (Sapling) }\end{array}$ & 693 & 18 & 0,225 & $3.080,0$ & 20,0 & 0,65 \\
\hline 3 & Tiang (Poles) & 320 & 8 & 0,900 & 35 & 8,9 & 2,50 \\
\hline 4 & Pohon (Tree) & 548 & 26 & 3,600 & 152,2 & 7,2 & 4,74 \\
\hline
\end{tabular}

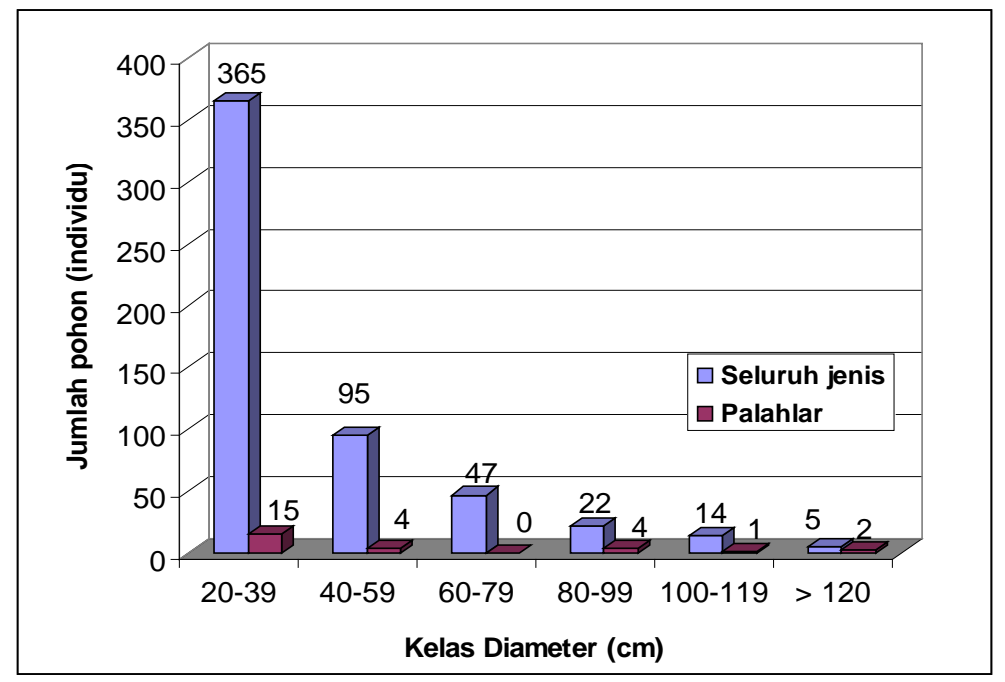

Gambar (Figure) 1. Sebaran jumlah pohon palahlar dan pohon seluruh jenis berdasarkan kelas diameter di lokasi penelitian (Number of tree for all species and palahlar species each diameter classes)

Pada Gambar 1 tampak bahwa bentuk sebaran banyaknya pohon berdasarkan kelas diameter membentuk huruf J terbalik atau membentuk struktur tegakan normal hutan tidak seumur, yaitu banyaknya pohon paling banyak pada kelas umur rendah dan semakin menurun dengan bertambahnya kelas diameter. Hal yang sama terjadi pada jenis palahlar, jumlah pohon palahlar paling banyak terdapat pada kelas diameter 20-39 cm sebanyak 15 pohon dan terus menurun hanya 2 pohon pada kelas diameter $120 \mathrm{~cm}$. Pada Gambar 1 dapat dilihat pula bahwa pohon-pohon di lokasi penelitian, baik palahlar maupun non palahlar masih ditemukan pohon-pohon besar dengan diameter batang $>120 \mathrm{~cm}$.
Hasil pengukuran dan perhitungan luas bidang dasar (lbds) atau sering disebut dengan basal area $\left(\mathrm{m}^{2} / \mathrm{ha}\right)$ tumbuhan tingkat tiang dan pohon untuk jenis palahlar dan semua jenis beserta persentasenya dapat dilihat pada Tabel 6 .

Pada Tabel 6 terlihat bahwa rata-rata basal area tumbuhan tingkat tiang (pohon berdiameter 10-20 cm) untuk seluruh jenis adalah $5,85 \mathrm{~m}^{2} /$ ha, basal area tingkat pohon seluruh jenis mencapai $26,17 \mathrm{~m}^{2} /$ ha, sedangkan untuk jenis palahlar masing-masing $0,15 \mathrm{~m}^{2} /$ ha untuk tingkat tiang dan 2,89 $\mathrm{m}^{2} /$ ha untuk tingkat pohon. Basal area palahlar pada tingkat tiang hanya 2,79\% dibandingkan dengan basal area seluruh jenis, sedangkan untuk tingkat pohon mencapai 8,67\%. Jika di- 
Tabel (Table) 6. Basal area tumbuhan tingkat tiang dan pohon untuk jenis palahlar dan semua jenis (Tree and poles stagebasal area for all species and palahlar species)

\begin{tabular}{ccccc}
\hline $\begin{array}{c}\text { Tingkat } \\
\text { (Growth stage) }\end{array}$ & Jalur (Transect) & $\begin{array}{c}\text { Basal area } \\
\text { palahlar (Basal } \\
\text { area of palahlar) } \\
\left(\mathrm{m}^{2} / \mathrm{ha}\right)\end{array}$ & $\begin{array}{c}\text { Basal area } \\
\text { seluruh jenis } \\
(\text { Basal area for all } \\
\text { species) } \\
\left(\mathrm{m}^{2} / \mathrm{ha}\right)\end{array}$ & $\begin{array}{c}\text { \% } \\
\text { Basal area } \\
\text { palahlar (Basal } \\
\text { area of palahlar) }\end{array}$ \\
\hline Tiang (Poles) & I & 0,04 & 6,68 & 0,58 \\
& II & 0,31 & 6,04 & 5,70 \\
& III & 0,10 & 4,82 & 2,08 \\
Pohon (Tree) & I & 0,15 & 5,85 & 2,79 \\
\hline Total (Totally) & III & 2,63 & 28,56 & 7,04 \\
\end{tabular}

jumlahkan basal area tingkat tiang dan pohon mencapai $3,04 \mathrm{~m}^{2} /$ ha atau $11,46 \%$. Nilai basal area tersebut tidak berbeda jauh dengan hasil-hasil penelitian basal area di hutan hujan dataran rendah di Sumatera. Nilai basal area dari pohon berdiameter $>15 \mathrm{~cm}$ dalam 17 petak penelitian masing-masing seluas 0,25 ha di Stasiun Penelitian Ketambe berkisar antara 16-45 m²/ha (Noorwiijk and Schaik, 1983 dalam Anwar et al., 1984).

\section{Karakteristik Tempat Tumbuh Dipterocarpus retusus}

Kelimpahan jenis pohon palahlar dan non palahlar berdasarkan ketinggian tempat, kelerengan tempat, dan sifat-sifat tanah dapat dilihat pada Tabel 7.

Pada Tabel 7 dapat dilihat berdasarkan pengukuran ketinggian tempat di lapangan, kelimpahan jenis palahlar mulai hadir pada ketinggian 1.000-1.299 m dpl. Di atas ketinggian $1.299 \mathrm{~m}$ dpl tidak ditemukan satupun jenis palahlar, baik yang berada dalam petak-petak pengamatan ataupun tidak. Pada ketinggian 1.000$1.099 \mathrm{~m}$ dpl ditemukan jenis palahlar gunung sebanyak 9 pohon. Pada ketinggian 1.100-1.199 m dpl ditemukan sebanyak 12 pohon dan pada ketinggian $1.200-$ $1.299 \mathrm{~m}$ dpl ditemukan sebanyak 5 pohon. Hal tersebut menunjukkan bahwa palahlar di lokasi kajian paling banyak ditemukan sampai ketinggian 1.299 m dpl, meskipun lokasi penelitian sampai ketinggian $1.599 \mathrm{~m}$ dpl.

Berdasarkan hasil pengukuran kelerengan tempat di lapangan, kelimpahan jenis palahlar gunung mulai hadir pada daerah yang berkelerengan 4-100\%. Untuk melihat pengaruh kelerengan terhadap keberadaan jenis palahlar gunung ini, maka kelerengan dibagi menjadi 4 kelas lereng, yaitu kelas lereng 1: 1-25\%; kelas lereng 2: 26-50\%; kelas lereng 3: 5175\%; dan kelas lereng 4: 76-100\%. Pada kelas lereng 2 kelimpahan palahlar gunung paling besar, yaitu sebanyak 15 pohon. Pada kelas lereng 3 dan 1 kelimpahan palahlar gunung sebanyak 5 dan 4 pohon dan kelimpahan palahlar gunung paling kecil terdapat pada kelas lereng 4, yaitu sebanyak 2 pohon.

Kelimpahan jenis palahlar berdasarkan ketinggian dan kelerengan tempat terdapat pada ketinggian 1.000-1.299 m dpl dengan kelerengan sebesar 4-100\%. Untuk kelimpahan jenis palahlar terbanyak terdapat pada ketinggian 1.100$1.199 \mathrm{~m}$ dpl dengan kelerengan sebesar 26-50\%. Sebaran tumbuhan palahlar di Gunung Cakrabuana ini sesuai dengan pendapat Newman et al. (1999) bahwa palahlar gunung ini hanya mampu tumbuh dan beradaptasi pada kisaran ketinggian antara 800-1.300 m dpl.

Pada Tabel 7 dapat dilihat bahwa kehadiran palahlar gunung dijumpai pada tanah dengan kelas tekstur geluh debuan, 
lempung dan kemasaman tanah kategori cukup masam sampai masam. Berdasarkan tekstur dan tingkat kemasaman tanah, palahlar gunung di lokasi penelitian terbanyak terdapat pada kelas tekstur tanah lempung dan kemasaman tanah kategori masam sampai cukup masam (pH 5,16,0) dan umumnya pada tanah Latosol.

Hasil analisis regresi berganda hubungan antara peubah jumlah pohon palahlar dan sifat-sifat fisik lingkungan (ketinggian tempat, topografi, dan sifat-sifat tanah) dengan menggunakan Minitab 14 dengan stepwise adalah sebagai berikut:

$$
\begin{aligned}
& \mathrm{Y}=\begin{array}{l}
-272-0.00661 \mathrm{X}_{1}-0.0256 \mathrm{X}_{2}+2.96 \mathrm{X}_{6} \\
\quad+2.81 \mathrm{X}_{7}+2.81 \mathrm{X}_{8}
\end{array} \\
& \mathrm{R}^{2}=85,3 \%
\end{aligned}
$$

Dimana :

$\mathrm{Y}=$ Jumlah pohon palahlar per petak

$\mathrm{X}_{1}=$ Ketinggian tempat $(\mathrm{m} \mathrm{dpl})$

$\mathrm{X}_{2}=$ Kelerengan (\%)

$\mathrm{X}_{6}=$ Kandungan pasir kedalaman tanah $>20 \mathrm{~cm}$ (\%)

$\mathrm{X}_{7}=$ Kandungan debu kedalaman tanah $>20 \mathrm{~cm}$ (\%)

$\mathrm{X}_{8}=$ Kandungan liat kedalaman tanah $>20 \mathrm{~cm}$ (\%)

Analisis keragaman dari model persamaan regresi linier berganda tersebut seperti tertera pada Tabel 8.

Tabel (Table) 7. Kelimpahan jenis palahlar berdasarkan jenis dan sifat fisik tanah, ketinggian dan kelerengan

\begin{tabular}{|c|c|c|c|c|c|c|c|}
\hline $\begin{array}{l}\text { Petak } \\
\text { (Plots) }\end{array}$ & $\begin{array}{l}\text { Jumlah } \\
\text { palahlar } \\
\text { (Number of } \\
\text { palahlar) }\end{array}$ & $\begin{array}{c}\text { Basal area } \\
\text { palahlar } \\
\text { (Basal area } \\
\text { palahlar }) \\
\left(\mathrm{m}^{2} / \mathrm{ha}\right)\end{array}$ & $\begin{array}{l}\text { Ketinggian } \\
\text { (Altitude) } \\
\text { (m dpl/asl.) }\end{array}$ & $\begin{array}{l}\text { Lereng } \\
\text { (Slope) } \\
(\%)\end{array}$ & $\begin{array}{c}\text { Kelas tekstur } \\
\text { tanah (Texture } \\
\text { classes) }\end{array}$ & $\begin{array}{l}\mathrm{pH} \\
\mathrm{H}_{2} \mathrm{O} \\
\text { tanah } \\
\text { (Soil) }\end{array}$ & $\begin{array}{c}\text { Tingkat } \\
\text { kemasaman } \\
\text { tanah (Soil } \\
\text { acidity level) }\end{array}$ \\
\hline 1 & 6 & 15,79 & $1.000-1.099$ & 33 & Geluh debuan & 5,4 & Masam \\
\hline 2 & 0 & 0 & 1.100-1.199 & 64 & Lempung & 5,1 & Sangat masam \\
\hline 3 & 0 & 0 & $1.200-1.299$ & 78 & Lempung & 5,3 & Masam \\
\hline 4 & 0 & 0 & 1.300-1.399 & 67 & $\begin{array}{l}\text { Geluh lem- } \\
\text { pung debuan }\end{array}$ & 5,1 & Sangat masam \\
\hline 5 & 0 & 0 & $1.400-1.499$ & 44 & Geluh debuan & 5,1 & Sangat masam \\
\hline 6 & 0 & 0 & $1.500-1.599$ & 38 & $\begin{array}{l}\text { Geluh lem- } \\
\text { pung debuan }\end{array}$ & 5,0 & Sangat masam \\
\hline 1 & 3 & 0,94 & $1.000-1.099$ & 22 & Geluh debuan & 5,9 & Cukup masam \\
\hline 2 & 11 & 12,28 & 1.100-1.199 & 44 & Lempung & 5,7 & Cukup masam \\
\hline 3 & 3 & 8,10 & 1.200-1.299 & 33 & Lempung & 5,7 & Cukup masam \\
\hline 4 & 0 & 0 & 1.300-1.399 & 44 & Lempung & 4,8 & Sangat masam \\
\hline 5 & 0 & 0 & $1.400-1.499$ & 62 & Geluh lempung & 5,0 & Sangat masam \\
\hline 6 & 0 & 0 & $1.500-1.599$ & 56 & $\begin{array}{l}\text { Geluh lem- } \\
\text { pung debuan }\end{array}$ & 5,4 & Masam \\
\hline 1 & 0 & 0 & $1.000-1.099$ & 56 & Lempung & 5,4 & Masam \\
\hline 2 & 1 & 1,18 & 1.100-1.199 & 100 & Lempung & 5,6 & Cukup masam \\
\hline 3 & 2 & 13,73 & $1.200-1.299$ & 89 & Lempung & 5,3 & Masam \\
\hline 4 & 0 & 0 & 1.300-1.399 & 67 & $\begin{array}{l}\text { Geluh lem- } \\
\text { pung debuan }\end{array}$ & 5,2 & Masam \\
\hline 5 & 0 & 0 & $1.400-1.499$ & 89 & $\begin{array}{l}\text { Lempung } \\
\text { debuan }\end{array}$ & 5,0 & Sangat masam \\
\hline 6 & 0 & 0 & $1.500-1.599$ & 78 & Lempung & 4,5 & Sangat masam \\
\hline
\end{tabular}
tempat (Palahlar species abundance related to soil properties, altitude and slope area)

Keterangan (Remarks):T = Ketinggian tempat (m dpl), L = Kelerengan tempat (\%)

Tabel (Table) 8. Analisis keragaman regresi linier berganda antara jumlah pohon palahlar per petak dengan faktor lingkungan di Hutan Lindung Gunung Cakrabuana, Sumedang (Analysis of variance for multi regression between number of palahlar tree and environment factors at Protected Forest of Cakrabuana Mountain, Sumedang)

\begin{tabular}{lccccc}
\hline \multicolumn{1}{c}{ Sumber keragaman (Source) } & $\mathrm{Db} / \mathrm{Df}$ & $\mathrm{JK} / S S$ & $\mathrm{KT} / M S$ & $\mathrm{~F} / F$ & $\mathrm{P} / P$ \\
\hline Regresi & 5 & 121.465 & 24.293 & 13.90 & 0.000 \\
Sisa & 12 & 20.980 & 1.748 & & \\
\hline Total & 17 & 142.444 & & & \\
\hline
\end{tabular}


Berdasarkan hasil analisis keragaman di atas, diperoleh nilai $\mathrm{P}=0,000$ yang berarti hubungan antara jumlah pohon palahlar per petak pengamatan (Y) dengan ketinggian tempat $\left(\mathrm{X}_{1}\right)$, kelerengan $\left(\mathrm{X}_{2}\right)$, kandungan pasir $\left(\mathrm{X}_{6}\right)$ pada kedalaman $>$ $20 \mathrm{~cm}$, kandungan debu pada kedalaman $>20 \mathrm{~cm}\left(\mathrm{X}_{7}\right)$, dan kandungan liat pada kedalaman $>20 \mathrm{~cm}\left(\mathrm{X}_{8}\right)$ sangat nyata dengan nilai $\mathrm{R}^{2}$ adalah $85,3 \%$. Faktor-faktor tempat tumbuh lainnya, yaitu tekstur tanah pada kedalaman 0-20 cm dan nilai pH kurang berpengaruh nyata.

Pada formula hubungan antara jumlah pohon palahlar dengan sifat-sifat lingkungan tempat tumbuh palahlar menunjukkan bahwa hubungan antara ketinggian tempat dan kelerengan adalah negatif, artinya semakin tinggi ketinggian tempat dan kelerengan jumlah palahlar semakin turun. Sementara hubungan antara jumlah pohon palahlar dengan kandungan pasir, debu dan liat pada kedalaman tanah di atas $20 \mathrm{~cm}$ bersifat respositif, artinya dengan meningkatnya kandungan pasir, debu dan liat jumlah pohon palahlar semakin banyak. Dengan demikian pertumbuhan palahlar di lokasi kajian sangat dipengaruhi oleh ketinggian tempat, kelerengan, dan tekstur tanah.

Hasil penelitian tersebut memperkuat pendapat beberapa ahli yang menyatakan bahwa palahlar gunung banyak tumbuh di hutan hujan pegunungan bawah pada ketinggian 800-1.300 m di Semenanjung Malaysia dan Jawa Barat, tetapi lebih rendah di daerah-daerah musiman hingga $100 \mathrm{~m}$ di Assam dan Lombok (Newman et al., 1999). Menurut Kartawinata (1983), jenis palahlar tempat tumbuhnya adalah hutan primer yang masih asli pada ketinggian 800-1.300 m, meskipun adakalanya terdapat pula pada ketinggian $100 \mathrm{~m}$ di daerah yang beriklim musiman, seperti di Lombok. Lebih lanjut Sastrapradja dan Kartawinata (1980) mengatakan pula bahwa tempat tumbuh jenis ini adalah di hutan primer atau belukar tua, tanah liat, berpasir atau berbatu di sepanjang sungai ataupun tempat kering. Jenis ini tumbuh mengelompok dan mungkin pada saat ini sudah jarang ditemukan di Jawa, dikarenakan hutan-hutan primernya sudah hampir punah (Kartawinata, 1983).

\section{KESIMPULAN DAN SARAN}

\section{A. Kesimpulan}

1. Jenis palahlar (Dipterocarpus retusus Bl.) di kawasan Hutan Lindung Gunung Cakrabuana bukan merupakan jenis dominan, namun semakin tinggi tingkat pertumbuhan semakin meningkat tingkat dominasinya terhadap jenis lain.

2. Jenis palahlar (D. retusus Bl.) di kawasan Hutan Lindung Gunung Cakrabuana dapat dijumpai pada ketinggian $1.000 \mathrm{~m}$ dpl sampai $1.225 \mathrm{~m}$ dpl dengan kelerengan tempat sebesar 4-100\%.

3. Kehadiran palahlar (D. retusus Bl.) di kawasan Hutan Lindung Gunung Cakrabuana sangat dipengaruhi ketinggian tempat, kelerengan tanah, dan tekstur tanah.

\section{B. Saran}

1. Dalam rangka penyelamatan jenis palahlar (D. retusus Bl.) di habitat aslinya sebagai konservasi plasma nutfah di Jawa Barat, kawasan Hutan Lindung Gunung Cakrabuana diusulkan sebagai kawasan konservasi dalam bentuk cagar alam.

2. Perlu terus dikembangkan teknik budidaya dan penanaman palahlar $(D$. retusus $\mathrm{Bl}$.). Untuk pengembangan atau penanaman palahlar $(D$. retusus Bl.) di luar habitatnya perlu memperhatikan ketinggian tempat, kelerengan, dan tekstur tanah.

\section{DAFTAR PUSTAKA}

Anwar, J., S.J. Damanik, N. Hisyam, dan A.J. Whitten. 1984. Ekologi eko- 
sistem Sumatera. Gadjah Mada University Press. Yogyakarta.

Heyne, K. 1987. Tumbuhan berguna Indonesia. Diterjemahkan oleh Badan Litbang Kehutanan. Yayasan Sarana Wana Jaya, Jakarta.

Kartawinata, K. 1983. Jenis-jenis keruing. Lembaga Biologi Nasional. LIPI. Bogor.

Misra, K.C. 1980. Manual of plant ecology. $2^{\text {nd }}$ Edition. Oxford and IBH Publishing Co. New Delhi.

Newman, M.F., P.F. Burgess, and T.C. Whitmore. 1999. Pedoman identifikasi pohon-pohon Dipterocarpaceae: Jawa sampai Niugini. PROSEA Indonesia. Bogor.

Sastrapradja, S. dan K. Kartawinata (Editors). 1980. Jenis-jenis kayu Indonesia. Balai Pustaka. Jakarta.
Smith, R.L. 1980. Ecology and field biology. $3^{\text {rd }}$ Edition. Harper and Row Publishers. New York.

Soerianegara, I. Dan A. Indrawan. 2002. Ekologi hutan Indonesia. Fakultas Kehutanan. Institut Pertanian Bogor.

Soerianegara, I. and R.H.J. Lemmens (Editors). 1994. Plant resources of South-East Asia 5 (1) timber trees: major commercial timbers. PROSEA, Bogor, Indonesia.

Southwood, T.R.E. and P.A. Henderson. 2000. Ecological methods. $3^{\text {rd }}$ Edition. Blackwell Science Ltd. Oxford. London.

Supranto, J. 1987. Statistik: teori dan aplikasi. Penerbit Erlangga. Jakarta. 